religion, race) and barriers to entry (apprenticeship, baptism, defended urban space). Since the way in which such boundaries are challenged and redefined helps determine the labor movement's successes and failures, "community" is likely to remain a key idea in working-class history for some time to come.

\title{
1996 French Historical Studies Conference
}

\section{Nicole Dombrowski}

Princeton University

The spirit of Versailles rather than of the Bourse du Travail animated the Forty-Second Annual Meeting of the Society for French Historical Studies, held at Boston University, March 21-23, 1996. Labor history as many of us first knew it-as an examination of workers' organizations or class struggle-barely appeared on this year's program. Instead, panels investigated the many aspects of the reign of Louis XIV, whose restoration as a subject of historical inquiry was marked by the fleur de lis imprinted on each page of the program. When in attendance, working men and women appeared most often outside of work: in their negotiations with the state, family members, religious institutions, police brigades, or neighborhood associations. The conference thus offered a glimpse of the remapping of French labor history.

The most innovative scholarship drew inspiration from the combined disciplines of labor and women's history. Lisa DiCaprio (Rutgers) and Janine Lanza (Cornell) offered original explanations of how independent and indigent working women negotiated the economic upheaval accompanying the transition from the Old Regime to the revolutionary economy. Lanza's paper on widows of master guild artisans argued against recent scholarship's claims that the Old Regime offered women more economic freedom and social maneuverability than did the post-revolutionary period. Her research documents that masters' widows' claims to status within the guilds, as well as their exercise of power within their own shops, met with constant challenges from sons, journeymen, and guild officials.

Di Caprio's detailed research on the revolutionary government's spinning workshops, established to absorb unemployed female laborers from the luxury industries, documented that spinners, weavers, and carders melded new ideas of patriotism, expectations for recently achieved rights, and some attributes of Old Regime paternalism to define a place for themselves in the new economic and political order.

The exploration of workers' relationships to the state became more 
complicated in panels focusing on World War Two. Talbot C. Imlay (Yale) reintroduced class struggle as a component of the 1938-1939 debates about whether the war economy should be planned or allowed to function in laissez-faire terms. Imlay reaffirmed that bitterness so alienated the French working class that government officials feared internal social strife would undermine national unity in a long-term conflict. Workers considered Reynaud's forty hours work law, the act to suppress the General Strike, and the arrests and convictions of striking workers as policies hostile to labor and serving the interests of capital. If class antagonism had indeed already corroded French fraternité, how should historians reevaluate working-class responsibility for a social fragmentation that might well have catalyzed France's collapse before Nazism and fueled the fratricidal battles waged during the Occupation and Liberation? Imlay's work suggests the field is ready for a more evenhanded, less polemical reexamination of this question.

Balancing working-class responsibility within explanations of France's fall and subsequent acts of collaboration is made difficult by stumbling attempts to chart the fine lines separating class interest, occupational selfinterest, and notions of patriotic and moral obligation. In this context Steven Zdatny (West Virginia University) offered a strange defense of the French Hairdressers' Union's support of Vichy's regressive Labor Charter. Zdatny categorized hairdressers as workers rather than entrepreneurs or artisans - a problem, since an understanding of how craft status conditioned how "workers" thought of themselves in political, pragmatic, or ideological terms is decisive for understanding why certain "workers" collaborated and others resisted the Vichy regime. Hairdressers, Zdatny claimed, supported Pétain as a means of restoring a moral economy which would end the violence of a liberal market, thus restraining unfair competition, reestablishing just prices, and restoring the artisanal integrity of the profession.

Zdatny considered the desires to order the "chaos" of syndicalism, commit to a classless society, and overthrow the yoke of a rank-and-file mentality "nonideological" commitments to Pétain's national revolution. Zdatny is not alone among a new brand of scholars who seek to blur the lines between left and right anticapitalism. His paper typified the trend in much new history of celebrating and highlighting the efforts of noncommunist workers, like hairdressers, as a potential third way of realizing occupational ambitions without fomenting class antagonisms. In reexamining the violence waged against workers under the Vichy regime, historians must cast a critical eye to idyllic aspirations for class harmony in the context of war and occupation. An interpretation defining any effort to achieve occupational self-empowerment as "good" or justifiable certainly errs when applied in the moral context of World War Two-and probably elsewhere as well.

However, Zdatny's paper raised the point that workers, regardless of 
how historians choose to define them, cannot always be counted upon to demonstrate moral righteousness. But to make a claim for the legitimacy or appropriateness of the Vichy Labor Charter based on the fact that members of the anticapitalist hairdresser's union supported it neglects the fact that other "workers" equally unhappy with the capitalist system, such as the railway workers, actively resisted the regime. Zdatny might have done hairdressers and workers more justice by investigating the aesthetics of fascist hairstyles rather than he did by drawing the conclusion that "workers" could find some aspects of Vichy Labor law redeeming. If historians begin to break down the category "working class," they are sure to find, especially in the context of World War Two, that what was "good" for some workers was not necessarily good for all.

\title{
For Us There Are No Frontiers: Global Approaches \\ to the Study of Italian Migration and the Making of Multiethnic Societies, 1800 to the Present
}

\author{
Michael Miller Topp \\ University of Texas at El Paso \\ Roberto Ventresca \\ University of Toronto
}

In early April 1996, nineteen scholars from seven countries met at L'Unione Italiana (the Italian Club) in Tampa, Florida, to examine the impact of Italian migration worldwide in roughly the last two centuries, not only on the countries to which these migrants went, but on Italy as well. The study of this migrant population is a massive undertaking, as the breadth of the papers showed: Between 1800 and 1970, twenty-six million Italians migrated within Europe or across oceans in search of work. Chronologically the papers extended from a piece by conference organizer Donna Gabaccia (University of North Carolina at Charlotte) on migration before and especially during the Risorgimento to work by Roberto Ventresca (University of Toronto) on the effect of the historical memory of Italo-Canadians' sympathy with and support for Fascism and Mussolini on the politics of ethnic identity in that community in the present day. Geographically, the papers presented explored Italian migration to other European countries, to South America and Central America, to Canada and the United States. 